\title{
A(H1N1)pdm09 influenza infection: vaccine inefficiency
}

\author{
Nehemya Friedman ${ }^{1,2, *}$, Yaron Drori ${ }^{1,2, *}$, Rakefet Pando ${ }^{3}$, Aharona Glatman- \\ Freedman ${ }^{3,4}$, Hanna Sefty ${ }^{3}$, Ravit Bassal', Yaniv Stein ${ }^{3}$, Tamy Shohat ${ }^{2,3}$, Ella \\ Mendelson $^{1,2}$, Musa Hindiyeh ${ }^{1,2}$, Michal Mandelboim ${ }^{1,2}$ \\ ${ }^{1}$ Central Virology Laboratory, Ministry of Health, Chaim Sheba Medical Center, Ramat-Gan, Israel \\ ${ }^{2}$ Department of Epidemiology and Preventive Medicine, School of Public Health, Sackler Faculty of Medicine, Tel-Aviv \\ University, Tel-Aviv, Israel \\ ${ }^{3}$ The Israel Center for Disease Control, Israel Ministry of Health, Tel-Hashomer, Israel \\ ${ }^{4}$ Departments of Pediatrics and Family and Community Medicine, Valhalla, New York, USA \\ *These authors contributed equally to this work
}

Correspondence to: Michal Mandelboim, email: michalman@sheba.health.gov.il

Keywords: influenza $A, H 1 N 1$, vaccine, Clade $6 B$

Received: November 22, $2016 \quad$ Accepted: March 14, 2017 Published: March 22, 2017

Copyright: Friedman et al. This is an open-access article distributed under the terms of the Creative Commons Attribution License (CC-BY), which permits unrestricted use, distribution, and reproduction in any medium, provided the original author and source are credited.

\section{ABSTRACT}

The last influenza pandemic, caused by the swine A(H1N1)pdm09 influenza virus, began in North America at 2009. Since then, the World Health Organization (WHO) recommended integration of the swine-based virus A/California/07/2009 strain in yearly vaccinations. Yet, infections with $A(H 1 N 1) p d m 09$ have continued in subsequent years. The reasons for this are currently unknown. During the 2015-2016 influenza season, we noted an increased prevalence of $A(H 1 N 1) p d m 09$ influenza virus infection in Israel. Our phylogenetic analysis indicated that the circulating A(H1N1)pdm09 strains belonged to 6B.1 and 6B.2 clades and differed from the vaccinating strain, with approximately 18 amino acid differences found between the circulating strains and the immunizing A/California/07/2009 strain. Hemmaglutination inhibition (HI) assays demonstrated higher antibodies titer against the $A / C a l i f o r n i a / 07 / 2009$ vaccinating strain as compared to the circulating Israeli strains. We thus suggest that the current vaccination was not sufficiently effective and propose inclusion of the current circulating $A(H 1 N 1) p d m 09$ influenza viruses in the annual vaccine composition.

\section{INTRODUCTION}

Influenza viruses are responsible for many respiratory infections affecting all age groups, particularly the elderly population $[1,2]$. Annual epidemics of seasonal influenza viruses are estimated to result in approximately three to five million cases of severe illness and about 250,000 to 500,000 deaths worldwide (WHO, 2014). In addition, influenza pandemics, that occur every few decades, pose a major global threat.

Influenza virus genome contains 8 single-stranded RNA molecules, which encodes at least 13 proteins, among them Neuraminidase (NA) and Hemagglutinin (HA), which are expressed on the surface of infected cells [3-5]. To avoid immune recognition, both the HA and the NA proteins are subjected to extensive antigenic changes, complicating the design of a universal vaccine aiming to target all influenza strains [6]. Thus, the primary preventive strategy currently available against influenza virus infection is a vaccine that is designed and administered each year [7]. The vaccine is composed of three or four influenza virus strains prevailing in the influenza season of the opposite hemisphere.

The most recent influenza pandemic occurred in 2009. Although the mortality rate was relatively low, it affected many people around the world [8]. The pandemic began in La Gloria, Mexico in February 2009 [9]. Since that time, the $\mathrm{A}(\mathrm{H} 1 \mathrm{~N} 1) \mathrm{pdm} 09$ virus spread rapidly across the globe and early assessments of transmissibility and severity were made [9]. In 2010, the WHO announced that $\mathrm{A}(\mathrm{H} 1 \mathrm{~N} 1) \mathrm{pdm} 09$ virus is expected to continue circulating as a seasonal virus [10]. Indeed, infections with the virus were noted in subsequent years, accounting for $24.5 \%$ of the 2010-2014 infections in North China, 16\% of which were in 2013-2014 [11]. In 2012-2013, 28.5\% of the influenza-infected individuals in France, Italy, Spain and 
Lithuania together, were infected with influenza A(H1N1) pdm09 [12]. In Austria, 18.3\% of the influenza-infected individuals were A(H1N1)pdm09-positive in winter 20142015 [13]. During the post-pandemic period in Israel, 10\% of the patients hospitalized in 2010-2011 winter season and 5\% of those hospitalized in the 2011-2012 winter season, were infected with the $\mathrm{A}(\mathrm{H} 1 \mathrm{~N} 1) \mathrm{pdm} 09$ virus [6]. These numbers rose in winter 2012-2013, when $20 \%$ of the hospitalized patients were infected with the $\mathrm{A}(\mathrm{H} 1 \mathrm{~N} 1)$ pdm09 influenza virus, $64.8 \%$ of whom were pregnant women [6]. A recent Eurosurveillance report estimated that the northern hemisphere vaccine still offers protection against circulating $\mathrm{A}(\mathrm{H} 1 \mathrm{~N} 1) \mathrm{pdm} 09$ viruses, because only limited drift has been observed [14].

Here, we report of a significant A(H1N1)pdm09 Influenza virus infection rate in the last winter season (20152016) in Israel, analyze the virus properties and demonstrate that it differs from the strain included in the vaccine.

\section{RESULTS}

\section{$A(H 1 N 1) p d m 09$ prevalence in Israel during the 2015-2016 winter season}

Samples of patients with Influenza-like illness (ILI) were obtained from 26 clinics around Israel, between September 2015 until March 2016. Among the tested samples, $45.12 \%$ (865 patients) proved positive for the presence of influenza viruses. Of these, $56.3 \%$ were positive for influenza $\mathrm{B}, 43.01 \%$ for $\mathrm{A}(\mathrm{H} 1 \mathrm{~N} 1) \mathrm{pdm} 09$, and only $0.7 \%$ for influenza $\mathrm{A}(\mathrm{H} 3 \mathrm{~N} 2)$ (Figure 1$)$. Interestingly, of the $\mathrm{A}(\mathrm{H} 1 \mathrm{~N} 1) \mathrm{pdm} 09$-infected individuals (372 patients), $14.5 \%$ (54 patients) had received the influenza vaccine. More intriguingly, among the $\mathrm{A}(\mathrm{H} 1 \mathrm{~N} 1) \mathrm{pdm} 09$ negative ILI patients (1545 patients), only $12.5 \%$ (194 patients) were vaccinated. Upon analysis of the weekly distribution of $\mathrm{A}(\mathrm{H} 1 \mathrm{~N} 1)$ pdm09 infection in 2015-2016, we noted that the infection began in week 48 of 2015 , peaked in the 3rd week of January 2016 and persisted until the end of March (week 12, 2016, Figure 2). When compared to influenza seasons 2013-2014 and 2014-2015, the 2015-2016 winter season was associated with a significant increase in $\mathrm{A}(\mathrm{H} 1 \mathrm{~N} 1)$ pdm09 infection-related infection (Figure 3).

\section{Genetic variations of seasonal A(H1N1)pdm09 viruses}

Several A(H1N1)pdm09 viruses were randomly selected from 2015-2016 winter period samples and from samples collected during previous winter seasons, to enable a whole $H A$ gene sequencing (1701 bp, 566 amino acid) and construction of a phylogenetic tree. Some of those viruses were isolated from individuals vaccinated against the California/07/2009 strain. We aligned 1035 base pairs of all the sequences in the phylogenetic tree. The resulting cladogram indicated that while the vaccinating strain A/California/07/2009 belongs to clade 1 , the circulating Israeli strains belonged to clade $6 \mathrm{~B}$, represented by A/South-Africa/3623/2013 (Figure 4). The Israeli strains belong either to clade 6B.1 or 6B.2, represented by A/Slovenia/2903/2015 or A/ Ukraine/6909/2015 strains, respectively (Figure 4).

Comparison of the Hemagglutinin sequences of the vaccine strain to those of the circulating Israeli strains belonging either to clade 6B.1 or to 6B.2 (represented by A/Israel/Q363/2015 and A/Israel/A6289/2015, respectively), identified 16 and 18 differences in the amino acid sequences, respectively (Table 1). All 6B clade viruses in our analysis contained the amino acid variations that define this clade: D97N, K163Q, S185T, S203T, A256T and K283E (Table 1) [15-17]. Additional mutations included S84N, S162N and I216T in the 6B.1 clade and V152T, V173I, E491G, D501E in the 6B.2 clade [18]. The last 7 mutations are located on the Hemagglutinin surface (Figure 5). There are four major antigenic sites on the Hemagglutinin protein named $-\mathrm{Sa}, \mathrm{Sb}, \mathrm{Ca}$, and $\mathrm{Cb}$ $[19,20]$. Mutations K163Q, S185T, S203T (clade 6B) are

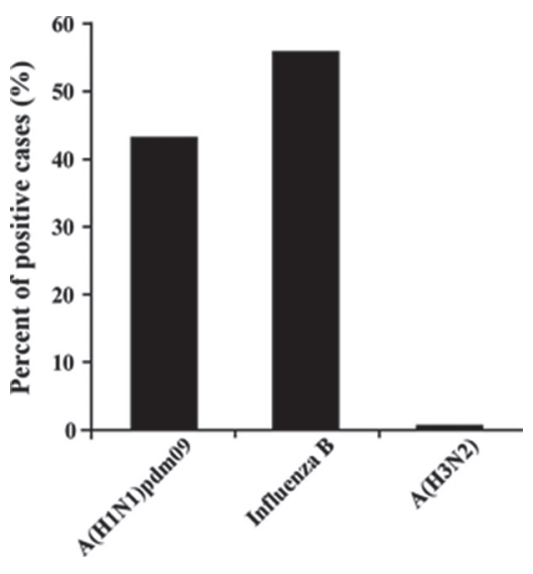

Figure 1: Percentages of influenza viruses. Distribution of influenza viruses strains (X axis) among 1917 influenza-positive cases in 2015-2016 winter season. 


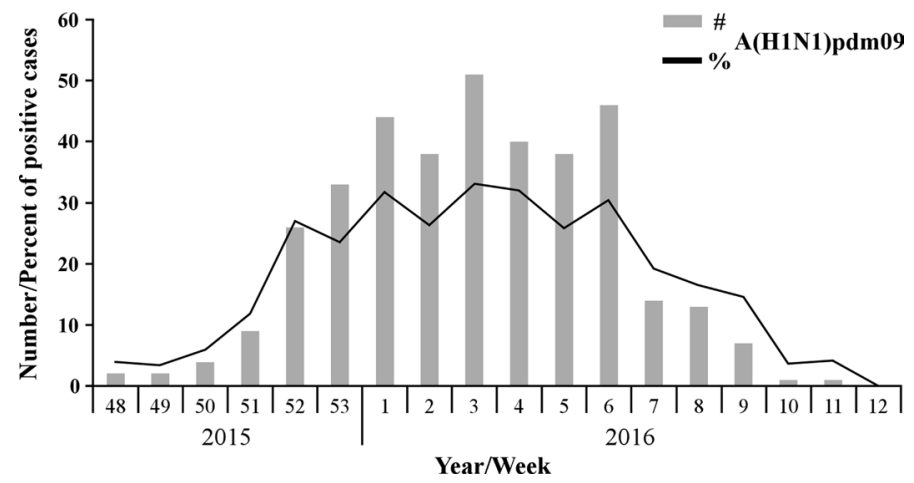

Figure 2: Distribution of A(H1N1)pdm09 infection in the 2015-2016 winter season. Number (\#) and percent (\%) of A(H1N1) pdm09-positive cases among 1917 samples collected during the 2015-2016 winter influenza season, starting from the 48th week of 2015 until the 12 th week of 2016.

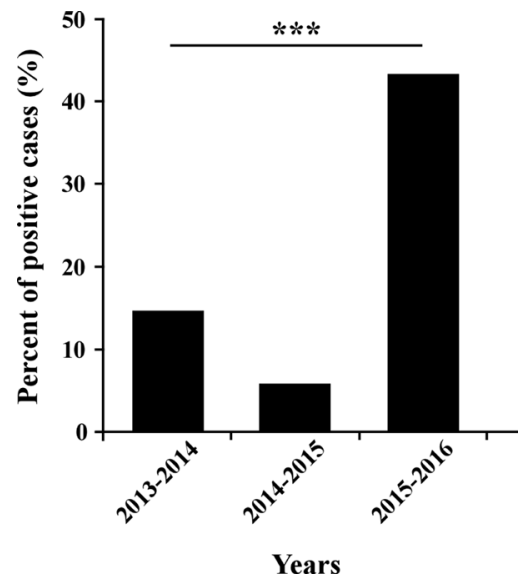

Figure 3: Percent of A(H1N1)pdm09 infection over the years. The annual percent of patients infected with the A(H1N1)pdm09 virus in winter seasons 2013-2014 (14.71\% of 503 positives for Influenza), 2014-2015 (5.81\% of 327) and 2016 (43.01\% of 865). *** indicates $P<0.0001$ using the chi-square test.

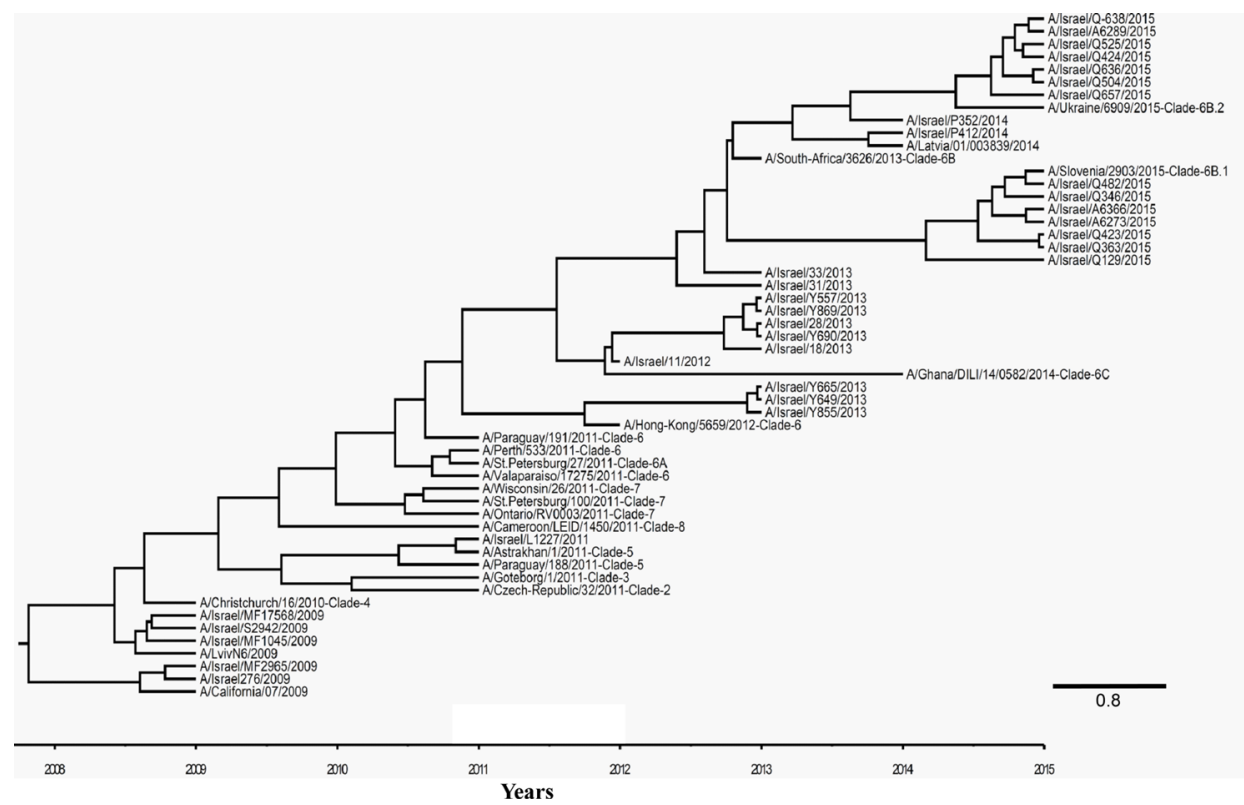

Figure 4: Phylogenetic tree of A(H1N1)pdm09 viruses. Bayesian maximum-clade-credibility time-scaled phylogenetic tree (BEAST), generated using $54 \mathrm{~A}(\mathrm{H} 1 \mathrm{N1})$ pdm09 Influenza HA gene, obtained from reference genes and patient samples collected between 2009 and 2016 in Israel. Alignment was observed for 1035 base pairs of all the genes in the phylogenetic tree. Clade number is indicated next to the reference viruses. Scale bar display time in years. 
Table 1: Mutations sequenced in Israeli 6B clade viruses

\begin{tabular}{|c|c|c|c|c|c|c|}
\hline \multirow{2}{*}{$\begin{array}{c}\begin{array}{c}\text { Amino Acid } \\
\text { position }\end{array} \\
83\end{array}$} & \multicolumn{2}{|c|}{$\begin{array}{c}\text { A/California/07/2009 } \\
\text { vaccine }\end{array}$} & \multicolumn{2}{|c|}{ A/Israel/Q363/2015 Clade 6B.1 } & \multicolumn{2}{|c|}{$\begin{array}{c}\text { A/Israel/A6289/2015 } \\
\text { Clade 6B.2 }\end{array}$} \\
\hline & CCT & $\mathrm{P}$ & TCT & $\mathrm{S}$ & TCT & $\mathrm{S}$ \\
\hline 84 & AGT & $\mathrm{S}$ & AAT & $\mathrm{N}$ & AGT & $\mathrm{S}$ \\
\hline 97 & GAT & $\mathrm{D}$ & AAT & $\mathrm{N}$ & AAT & $\mathrm{N}$ \\
\hline 152 & GTT & $\mathrm{V}$ & GTT & $\mathrm{V}$ & $\mathrm{ACT}$ & $\mathrm{T}$ \\
\hline 162 & $\mathrm{AGC}$ & $\mathrm{S}$ & AAC & $\mathrm{N}$ & $\mathrm{AGC}$ & $\mathrm{S}$ \\
\hline 163 & AAA & $\mathrm{K}$ & $\mathrm{CAA}$ & Q & $\mathrm{CAA}$ & $\mathrm{Q}$ \\
\hline 173 & GTC & $\mathrm{V}$ & GTC & $\mathrm{V}$ & ATC & I \\
\hline 185 & AGT & $\mathrm{S}$ & $\mathrm{ACT}$ & $\mathrm{T}$ & $\mathrm{ACT}$ & $\mathrm{T}$ \\
\hline 187 & GAG & $\mathrm{E}$ & GAC & $\mathrm{D}$ & GAC & $\mathrm{D}$ \\
\hline 203 & TCA & $\mathrm{S}$ & ACA & $\mathrm{T}$ & $\mathrm{ACA}$ & $\mathrm{T}$ \\
\hline 216 & GCA & $\mathrm{A}$ & ACA & $\mathrm{T}$ & ATA & $\mathrm{I}$ \\
\hline 224 & GCA & $\mathrm{A}$ & GAA & $E$ & GAA & $\mathrm{E}$ \\
\hline 256 & GCA & $\mathrm{A}$ & $\mathrm{ACA}$ & $\mathrm{T}$ & $\mathrm{ACA}$ & $\mathrm{T}$ \\
\hline 273 & $\overline{\mathrm{CAC}}$ & $\mathrm{H}$ & $\mathrm{CAC}$ & $\mathrm{H}$ & $\overline{\mathrm{CAC}}$ & $\mathrm{H}$ \\
\hline 283 & AAG & $\mathrm{K}$ & GAG & $E$ & GAG & $E$ \\
\hline 321 & ATC & $\mathrm{I}$ & GTC & $\mathrm{V}$ & GTC & $\mathrm{V}$ \\
\hline 374 & GAG & $\mathrm{E}$ & $\mathrm{AAG}$ & $\mathrm{K}$ & AAA & $\mathrm{K}$ \\
\hline 451 & AGC & $\mathrm{S}$ & $\mathrm{AAC}$ & $\mathrm{N}$ & $\mathrm{AAC}$ & $\mathrm{N}$ \\
\hline 491 & GAG & $\mathrm{E}$ & GAG & $E$ & GGG & $\mathrm{G}$ \\
\hline 499 & GAA & $\mathrm{E}$ & AAA & $\mathrm{K}$ & $\mathrm{AAA}$ & $\mathrm{K}$ \\
\hline 501 & GAT & $\mathrm{D}$ & GAT & $\mathrm{D}$ & GAA & $E$ \\
\hline $\begin{array}{c}\text { Total } \\
\text { Differences }\end{array}$ & & & & 16 & & 18 \\
\hline
\end{tabular}

A list of mutations and their amino acid position as found in sequencing 6B.1 (A/Israel/Q363/2015) and 6B.2 (A/Israel/ A6289/2015) clade viruses, in comparison to the vaccine strain (A/California/07/2009).

respectively located on $\mathrm{Sa}, \mathrm{Sb}$ and $\mathrm{Ca} 1$ antigenic sites. In addition, we found that S162N (clade 6B.1) located in Sa site [21] and V173I (clade 6B.2) in Ca1 site [15].

\section{Immunity to old and new A(H1N1)pdm09 antigens}

Analysis of the symptoms reported by patients infected with $\mathrm{A}(\mathrm{H} 1 \mathrm{~N} 1)$ pdm09 virus in 2009 and 2012 versus 2015th circulating 6B clade strains, yielded no significant differences between the patient groups (Figure 6). In addition, to evaluate the potential of serum antibodies collected from individuals to cross-react with the influenza A(H1N1)pdm09 circulating strains, sera from 240 individuals obtained in 2014-2015, prior to the appearance of the current strains. Sera samples were applied in HI assays against the vaccine strain $\mathrm{A} / \mathrm{California} / 07 / 2009$ antigen and against two circulating influenza $\mathrm{A}(\mathrm{H} 1 \mathrm{~N} 1) \mathrm{pdm} 09$ antigens from clade 6B.1 and 6B.2. As seen in Figure 7, the vaccine strain was better recognized (Figure 7A), and yielded a higher geometric mean of antibodies titer (GMT Figure 7B), as compared with the circulating Israel strains.

\section{DISCUSSION}

The recent years gave us the opportunity to study the evolution and spread of the pandemic $\mathrm{A}(\mathrm{H} 1 \mathrm{~N} 1)$ pdm09 Influenza virus, since the time it first appeared in 2009 until today. At the post-pandemic period, until 2015, HA genes have evolved and eight genetic groups have been designated [6]. Since September 2015, most $\mathrm{A}(\mathrm{H} 1 \mathrm{~N} 1) \mathrm{pdm} 09$ viruses fell into genetic group $6 \mathrm{~B}$ and in two emerging subgroups, 6B.1 and 6B.2 [18]. Despite the emergence of new genetic subgroups, a report for the WHO suggested in February 2016 that these 6B clade viruses are antigenically similar to the vaccine virus $\mathrm{A} /$ California/7/2009 [18].

During the 2015-2016 influenza season at total of 1548 outpatient samples were negative for influenza, of which $194(12.5 \%)$ of them were vaccinated against influenza. To test the vaccination efficiency we compared the odds ratio of vaccinated and non-vaccinated individuals among individuals who were positive and negative for influenza. The odds ratio was 1.18 , indicating no difference between the vaccinated and the none- 


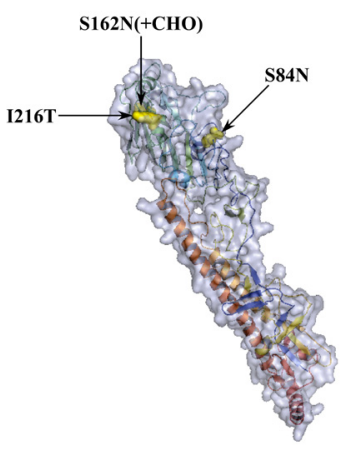

A/Israel/Q363/2015 Clade 6B.1

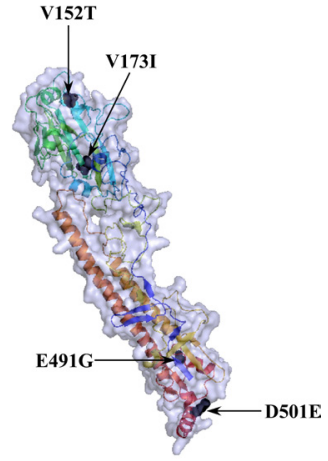

A/Israel/A6289/2015

Clade 6B.2

Figure 5: Three dimensional presentation of $\mathrm{HA}$ protein of circulating 6B clade Israeli viruses. $H A$ gene sequences of A/ Israel/Q363/2015 (clade 6B.1) and A/Israel/A6289/2015 (clade B.2) translated using ExPASy translate tool and their 3D structure predicted using SWISS-MODLE server. The tertiary structure designed in PyMOL. Mutations which define 6B.1 (yellow) or 6B.2 clade (black) are marked in arrow.

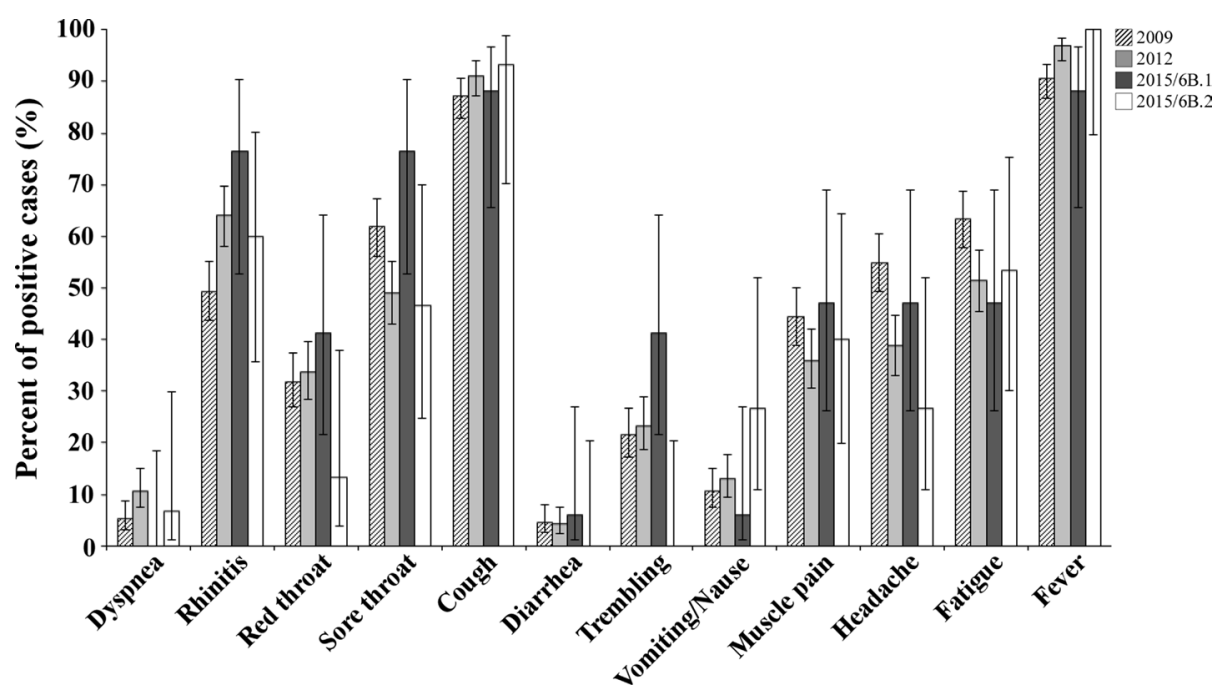

Figure 6: Clinical characteristics of patients infected with 6B clade A(H1N1)pdm09 viruses. A summary of the clinical symptoms of Israeli patients infected in 2015-2016with A(H1N1)pdm09 virus belonging to the 6B.1 or 6B.2 clade.
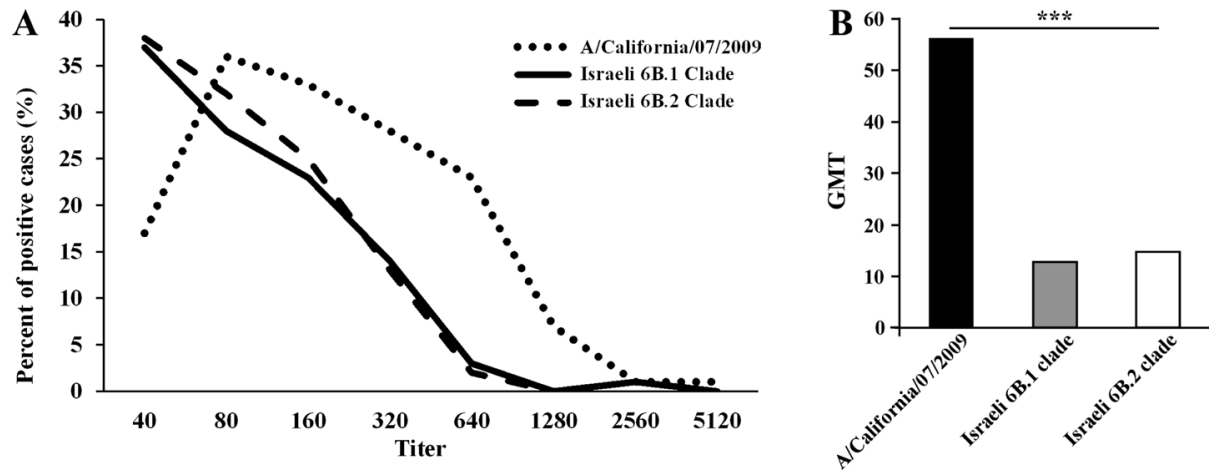

Figure 7: Antibodies against 6B clade antigens were not dominant in 2014. The presence of antibodies against A/ California/07/2009, Israeli 6B.1 and 6B.2 antigens was detected using the HI test. The figure shows the distribution of the positive cases by antibody titer (A) and their geometric mean (B). *** indicates $P<0.0001$ using the Kruskal-Wallis test. 
vaccinated individuals. The circulating Israeli strains were shown phylogenetically differ from the vaccinating A/California/7/2009 A(H1N1)pdm09 strain, with the vaccinating strain belonging to clade 1 , and the circulating strains belonging to clades 6B.1 and 6B.2. Furthermore, approximately 18 amino acid modifications were identified between the circulating Israeli strains and the vaccinating strain. Some of these mutations are located in antigenic sites [15, 19-21], and therefore might result in ineffective immunogenic recognition.

Laboratories in the United States and United Kingdom have recently reported maintained effectiveness of the influenza vaccine bearing the A/California/7/2009 strain $[22,23]$. However, in contrast to these reports, which used post-infected ferret's sera in their HI assays, we directly compared the HI potential of A/California/7/2009 versus Israeli $6 \mathrm{~B}$ viruses isolated from patient samples, to identify cross-protecting antibodies in the Israeli population. This analysis significantly demonstrate that the anti-influenza antibodies recognize the circulating Israeli 6B strains 4-fold less efficiently as compared to the vaccinating strain. In line with these findings, the WHO report including recommendations for the northern hemisphere 2015-2016 vaccine composition, states that the GMTs in HI against representative 6B clade viruses were significantly reduced compared to HI titers to the vaccine virus, particularly in pediatric serum panels [18].

In the past seven years, the A/California/7/2009 strain has been included in the influenza vaccine [24]. However, we show here that the circulating $\mathrm{A}(\mathrm{H} 1 \mathrm{~N} 1)$ pdm09 viruses substantially differ from the vaccinating strains and are not adequately recognized by the vaccine strains. In view of these results, we suggest that current circulating strains should be included in the vaccine.

\section{MATERIALS AND METHODS}

\section{Patients and samples}

As part of community influenza surveillance, conducted in collaboration with the Israel Center for Disease Control (ICDC), respiratory clinical samples (nosethroat swabs) were collected from 1917 patients presenting with Influenza-like illness (ILI), during the winter season spanning between October 2015 and April 2016.

Serum samples $(N=240)$ were obtained from the Israel National Serum Bank established by the Israel Center for Disease Control. The samples were collected from healthy individuals in 2014.

\section{Detection of $A(H 1 N 1) p d m 09$ virus}

Viral genomic RNA was extracted from patient samples using the NucliSENS easyMAG (BioMerieux,
France). Influenza A, influenza B and A(H1N1)pdm09 strains were identified using a panel of real-time reverse transcription PCR (rRT-PCR), as previously described [25, 26].

\section{Sample preparation for sequencing}

For the phylogenetic analysis, influenza Hemagglutinin gene-specific primers (WHO Swine genome set [27] were amplified using the OneStep RTPCR Kit (QIAGEN). ExoProStar (Illustrsa) was activated on the cDNA to clean unincorporated primers and dNTPs. The Big Dye ${ }^{\circledR}$ Terminator v1.1 cycle kit $\left(\right.$ ABI Prism ${ }^{\circledR}$ ) was used for sample sequencing, as per the manufacturer's instructions. The BigDye ${ }^{\circledR}$ Xterminator Purification Kit (ABI) was then used to clean the cDNA. Samples were processed and sequenced in a Genetic Analyzer 3500 (ABI $\backslash$ HITACHI) machine.

\section{Phylogenetic analysis}

For the phylogenetic analysis, Influenza Hemagglutinin gene-specific primers were used [6, 27]. The Sequencher ${ }^{\circledR} 5.0$ program (Gencodes Corporation, Ann Arbor, MI) was used to compare the nucleotide sequences of the collected samples to $H A$ genes of various Influenza A clades.

The evolutionary relationships and the most recent common ancestor (MRCA) for the influenza A(H1N1)pdm09 virus Hemagglutinin sequences, were calculated using a Bayesian Markov chain Monte Carlo (MCMC) method, applied using a relaxed molecular clock, as implemented in the BEAST program (version 1.7.5). Trees were visualized and edited with the Figure Tree program (version 1.4.2) included in the BEAST software package [28].

\section{Hemagglutination inhibition (HI) analysis}

All sera were treated $(16 \mathrm{~h})$ with receptor destroying enzyme (RDE) (Sigma C8772), diluted 1:4, prior to heat inactivation $\left(30 \mathrm{~min}, 56^{\circ} \mathrm{C}\right)$. Absorption with erythrocytes was then conducted to remove non-specific binding, in accordance with a WHO-recommended protocol [29]. Two-fold serial dilutions (1:40-1:5120) of sera in $25 \mu \mathrm{l}$ PBS were prepared in V-shaped well plates, and an equal volume of four HA units was added. The mixture was then incubated at room temperature for $1 \mathrm{~h}$. Fifty microliters of $0.5 \%$ chicken erythrocytes suspended in PBS, were added to the wells, and mixed by shaking the plates on a mechanical vibrator. Agglutination patterns were read after $30 \mathrm{~min}$ and the HI titer was defined as the reciprocal of the last dilution of serum that fully inhibited Hemagglutination. The cut-off value for a positive result was set at 1:40. The influenza A(H1N1)pdm09 (A/ California/07/2009 NYMC X-179A) antigen was supplied 
by the WHO. The Israeli 6B.1 and 6B.2 clades antigens were $\mathrm{A} / \mathrm{Israel} / \mathrm{Q} 363 / 2015$ and $\mathrm{A} / \mathrm{Israel} / \mathrm{Q} 504 / 2015$, respectively.

\section{Statistical analysis}

The annual percent of positive cases was calculated by dividing the number of positive $\mathrm{A}(\mathrm{H} 1 \mathrm{~N} 1) \mathrm{pdm} 09$ samples by the total number of positive tests for Influenza Viruses. The Chi-Square test was applied to evaluate the differences in positivity percent between the compared years. To calculate significant differences of HI results, we used Kruskal-Wallis test (One-way ANOVA on ranks), since the titers have non-normal distributions. All analyses were performed using SPSS. A $p$-value $<0.05$ was considered to be statistically significant.

\section{Ethical considerations}

Community influenza surveillance, including nose-throat swabs, is performed under the Public Health Ordinance enacted in Israel and thus informed consent was not required. The IRB of the Sheba Medical Center approved the research (Helsinki Number 2873-15-SMC for molecular characterization and 1967-15-SMC for serologic studies).

This work was performed in partial fulfillment of the requirements for a Ph.D degree of Nehemya Friedman, Sackler Faculty of Medicine, Tel Aviv University, Israel.

\section{CONFLICTS OF INTEREST}

None.

\section{REFERENCES}

1. Thompson WW, Shay DK, Weintraub E, Brammer L, Bridges CB, Cox NJ, Fukuda K. Influenza-associated hospitalizations in the United States. JAMA. 2004; 292:1333-1340.

2. Taubenberger JK, Kash JC. Influenza virus evolution, host adaptation, and pandemic formation. Cell Host Microbe. 2010; 7:440-451

3. Jagger BW, Wise HM, Kash JC, Walters KA, Wills NM, Xiao YL, Dunfee RL, Schwartzman LM, Ozinsky A, Bell GL, Dalton RM, Lo A, Efstathiou S, et al. An overlapping protein-coding region in influenza A virus segment 3 modulates the host response. Science. 2012; 337:199-204.

4. Rossman JS, Lamb RA. Influenza virus assembly and budding. Virology. 2011; 411:229-236.

5. Nayak DP, Hui EK, Barman S. Assembly and budding of influenza virus. Virus Res. 2004; 106:147-165.

6. Sherbany H, McCauley J, Meningher T, Hindiyeh M, Dichtiar R, Markovich MP, Mendelson E, Mandelboim M.
Return of pandemic H1N1 influenza virus. BMC Infect Dis. 2014; $14: 710$.

7. Cox NJ, Subbarao K. Influenza. Lancet. 1999; 354:1277-1282.

8. Neumann G, Noda T, Kawaoka Y. Emergence and pandemic potential of swine-origin H1N1 influenza virus. Nature. 2009; 459:931-939.

9. Fraser C, Donnelly CA, Cauchemez S, Hanage WP, Van Kerkhove MD, Hollingsworth TD, Griffin J, Baggaley RF, Jenkins HE, Lyons EJ, Jombart T, Hinsley WR, Grassly NC, et al. Pandemic potential of a strain of influenza A (H1N1): early findings. Science. 2009; 324:1557-1561.

10. WHO recommendations for the post-pandemic period. WHO: World Health Organization). 2009.

11. Han Y, Sun N, Lv QY, Liu DH, Liu DP. Molecular epidemiology and phylogenetic analysis of HA gene of influenza A(H1N1)pdm09 strain during 2010-2014 in Dalian, North China. Virus Genes. 2016; 52:606-612.

12. Rondy $\mathrm{M}$, Launay $\mathrm{O}$, Puig-Barberà $\mathrm{J}$, Gefenaite $\mathrm{G}$, Castilla J, de Gaetano Donati K, Galtier F, Hak E, Guevara M, Costanzo S, Moren A, network EhI. 2012/13 influenza vaccine effectiveness against hospitalised influenza A(H1N1)pdm09, A(H3N2) and B: estimates from a European network of hospitals. Euro Surveill. 2015; 20.

13. Redlberger-Fritz M, Kundi M, Popow-Kraupp T. Detailed Report on 2014/15 Influenza Virus Characteristics, and Estimates on Influenza Virus Vaccine Effectiveness from Austria's Sentinel Physician Surveillance Network. PLoS One. 2016; 11:e0149916.

14. Broberg E, Snacken R, Adlhoch C, Beauté J, Galinska M, Pereyaslov D, Brown C, Penttinen P, Network WERatEIS. Start of the 2014/15 influenza season in Europe: drifted influenza A(H3N2) viruses circulate as dominant subtype. Euro Surveill. 2015; 20.

15. Broberg E, Melidou A, Prosenc K, Bragstad K, Hungnes O, countries WERatEISNmotr. Predominance of influenza A(H1N1)pdm09 virus genetic subclade 6B.1 and influenza $\mathrm{B} /$ Victoria lineage viruses at the start of the 2015/16 influenza season in Europe. Euro Surveill. 2016; 21.

16. Daniels R, Gregory V, McCauley J. (December 2013). Surveillance Report; Influenza Virus characterisation.

17. Parida M, Dash PK, Kumar JS, Joshi G, Tandel K, Sharma S, Srivastava A, Agarwal A, Saha A, Saraswat S, Karothia D, Malviya V. Emergence of influenza A (H1N1) pdm09 genogroup 6B and drug resistant virus, India, January to May 2015. Euro Surveill. 2016; 21:6-11.

18. McCauley J, Daniels R, Lin YP, Xiang Z, Gregory V, Whittaker L, Halai C, Cross K, Rattigan A, Ermetal B, Dai M. (February 2016). Report prepared for the WHO annual consultation on the composition of influenza vaccine for the Northern Hemisphere 2016-2017.

19. Gerhard W, Yewdell J, Frankel ME, Webster R. Antigenic structure of influenza virus haemagglutinin defined by hybridoma antibodies. Nature. 1981; 290:713-717. 
20. Caton AJ, Brownlee GG, Yewdell JW, Gerhard W. The antigenic structure of the influenza virus $\mathrm{A} / \mathrm{PR} / 8 / 34$ hemagglutinin (H1 subtype). Cell. 1982; 31:417-427.

21. Wilson JR, Guo Z, Tzeng WP, Garten RJ, Xiyan X, Blanchard EG, Blanchfield K, Stevens J, Katz JM, York IA. Diverse antigenic site targeting of influenza hemagglutinin in the murine antibody recall response to $\mathrm{A}(\mathrm{H} 1 \mathrm{~N} 1) \mathrm{pdm} 09$ virus. Virology. 2015; 485:252-262.

22. Pebody R, Warburton F, Ellis J, Andrews N, Potts A, Cottrell S, Johnston J, Reynolds A, Gunson R, Thompson C, Galiano M, Robertson C, Mullett D, et al. Effectiveness of seasonal influenza vaccine in preventing laboratoryconfirmed influenza in primary care in the United Kingdom: 2015/16 mid-season results. Euro Surveill. 2016; 21.

23. Flannery B, Chung J. Influenza Vaccine Effectiveness, Including LAIV vs IIV in Children and Adolescents, US Flu VE Network, 2015-16.

24. Koul PA, Broor S, Saha S, Barnes J, Smith C, Shaw M, Chadha M, Lal RB. Differences in influenza seasonality by latitude, northern India. Emerg Infect Dis. 2014; 20:1723-1726.
25. Hindiyeh M, Ram D, Mandelboim M, Meningher $T$, Hirsh S, Robinov J, Levy V, Orzitzer S, Azar R, Grossman Z, Mendelson E. Rapid detection of influenza A pandemic (H1N1) 2009 virus neuraminidase resistance mutation $\mathrm{H} 275 \mathrm{Y}$ by real-time reverse transcriptase PCR. J Clin Microbiol. 2010; 48:1884-1887.

26. Panning $\mathrm{M}$, Eickmann $\mathrm{M}$, Landt O, Monazahian M, Olschläger S, Baumgarte S, Reischl U, Wenzel JJ, Niller HH, Günther S, Hollmann B, Huzly D, Drexler JF, et al. Detection of influenza $\mathrm{A}(\mathrm{H} 1 \mathrm{~N} 1) \mathrm{v}$ virus by real-time RT-PCR. Euro Surveill. 2009; 14.

27. World Health Organization. Sequencing primers and protocol. (May, 2009).

28. Drummond AJ, Suchard MA, Xie D, Rambaut A. Bayesian phylogenetics with BEAUti and the BEAST 1.7. Mol Biol Evol. 2012; 29:1969-1973.

29. Smithwick RW, Influenza WCCfRaRo, Control CfD, Services USDoHaH, Vaccines WCCfRaRaV. (1982). Concepts and Procedures for Laboratory-based Influenza Surveillance: U.S. Department of Health and Human Services). 